\title{
Addressing the Implementation Challenges of Institutional Obligations and Reporting Requirements under the Nigerian Freedom of Information Act 2011
}

\author{
Ngozi J. Udombana \\ Nigerian Institute of Advanced Legal Studies, Lagos, Nigeria \\ Email: ebubechi8@yahoo.com
}

How to cite this paper: Udombana, N. J. (2019). Addressing the Implementation Challenges of Institutional Obligations and Reporting Requirements under the Nigerian Freedom of Information Act 2011. Beijing Law Review, 10, 1305-1330.

https://doi.org/10.4236/blr.2019.105070

Received: May 16, 2019

Accepted: December 13, 2019

Published: December 16, 2019

Copyright () 2019 by author(s) and Scientific Research Publishing Inc. This work is licensed under the Creative Commons Attribution International License (CC BY 4.0).

http://creativecommons.org/licenses/by/4.0/

(c) (i) Open Access

\begin{abstract}
Access to information is critical to the realisation of an accountable government. The enactment of Nigeria's Freedom of Information Act in 2011 ushered in a fresh hope of imminent victory over the culture of secrecy that had always defined the Nigerian public service. The Act provides for public access to public record and information; obligates public institutions to maintain records and allow public access to information, among other things. It establishes procedures for the achievement of these purposes. This paper examines the institutional and reporting requirements provisions, which constitute part of the goal of the Act to enhance the availability and accessibility of public records and information. The paper finds that, lofty as these provisions are, there are gaps in the law. These gaps include ambiguity in some of the provisions and failure to provide requisite sanctions for noncompliance with certain provisions of the law. There are also the challenges of the pervasive culture of not keeping record by public institutions and lack of sufficient will on the part of the Attorney-General of the Federation and Minister of Justice, who is the chief implementing officer of the Act, to ensure the success of the goal of the Act. In order to address these challenges, the paper recommends, among others, that the identified gaps be filled, adequate sanctions be provided for noncompliance with relevant provisions of the law while the few sanctions already provided for in the Act should be effectively enforced.
\end{abstract}

\section{Keywords}

Challenges, Freedom, Implementation, Information, Institutional Obligation, Reporting Requirements 


\section{Introduction}

Public bodies hold information not for themselves but as custodians of the public good and everyone has a right to access this information, subject only to clearly defined rules established by law (Sendugwa, 2010; Mendel, 2003). On 24 May 2011, the Nigerian National Assembly, bowing to sustained public demand, passed the Freedom of Information Bill into law. The Assent of President Goodluck Jonathan to the Bill on 28 May 2011, finally put paid to the Bill's 11 years tortuous journey. The Bill had suffered several defeats in the hands of previous lawmakers, despite the admission of the timeliness of the Bill by the leaders of the Assembly and their promise to speedily pass it (ARTICLE 19, 2007). The passage of this Bill, which brought Nigeria into the league of African nations that have done so (Anukam, 2015), is clearly a step generally meant to foster our nascent democracy and development in the country. Information is the stimulus of all the thoughts and actions of living creatures; it is a prerequisite for the functioning of the modern society as success in every area of human endeavour is premised on its intelligent use (Omotayo, 2015).

Nigeria has a low threshold of accountability and transparency. So much administrative and governmental issues are shrouded in secrecy (Daily Trust Editorial, 2016), sometimes almost to the level of cultism. Public servants are made to swear to oaths of secrecy in addition to other laws prohibiting access to information such as the Official Secrets Act, (Cap 03 Laws of the Federation of Nigeria (LFN) 2004) among others (Freedom of Information Coalition, 2010). Inokoba (2014) opines that the weight of the truth of the fact that information is the life blood of democracy and, without adequate access, citizens and parliamentarians cannot make informed decisions, thus promoting incompetency under the guise of secrecy, is felt even more seriously in undeveloped nations where corruption and secrecy is the norm rather than the exception. It is therefore less surprising that the struggle for the legalisation of the public right to information in Nigeria took long years of patient, tortuous and contentious battle by civil liberty organisations (See also Ekuno, 2001). Reinforcing this point, Mrs. Justina Suwa, the Legal Adviser, Federal Ministry of Works, recently noted that "moving from the culture of secrecy to openness was a major challenge facing the implementation of the FOI in the civil service." She, therefore, advocated increased sensitisation exercise to make civil servants realise that the Freedom of Information Act (FOIA) is not an enemy, but a good tool in fighting corruption. This would make them more open to giving information (Vanguard, 2016; Madubuike \& Mbadugha, 2018). Underscoring the importance of availability of information in the realisation of good governance, Dakas (2009) notes that the conduct of governmental affairs in absolute secrecy is antithetical to the task of engendering democratic governance within the framework of transparency and accountability.

Section 22 of the Nigerian Constitution of the Federal Republic of Nigeria 1999, as amended (CFRN) directs the press, radio, television, and other agencies 
of the mass media to, at all times, be free to uphold the fundamental objectives contained in Chapter II of the Constitution and uphold the responsibility and accountability of the Government to the people while section 24 imposes a duty on every citizen to, among other things, help enhance the power, prestige and good name of Nigeria; and make positive and useful contribution to the advancement, progress and well-being of the community where he resides. The fulfilment of this duty demands that the citizens take seriously their responsibility to act as watchdogs over governmental affairs. The Freedom of Information Act, thus, places Nigerians in a position to, in an informed way, play this role and ensure transparency and accountability in governance.

The Long Title to the FOI Act, 2011 states that it is an Act to, among others, make public records and information more freely available, provide for public access to public records and information, protect public records and information to the extent consistent with the public interest and establish procedures for the achievement of those purposes and for related matters. This paper discusses the institutional and reporting requirements provisions, which aims to assist in realising the above goals of the Act; the associated implementation challenges and how to address them. The paper is divided into five parts of which this introduction forms Part I. Part II explains the right to information, Part III discusses the institutional obligations and their associated challenges. Part IV addresses the reporting requirements and its challenges while Part V makes some recommendations and concludes the paper. Critical analysis of issues and suggestions are infused into the discussions of the segments. Existing gaps and implementation challenges are identified and solutions proffered.

\section{What Is Right to Information (RTI)?}

Right to information (RTI) and freedom of information (FOI) are used interchangeably. RTI is the freedom of people to have access to government's information. It is the ability of citizens and nongovernmental organisations to enjoy reasonable free access to all files and documents pertaining to governmental operations, decisions, and performance (Torres, 2012). It is also the universal right to access information held by public bodies. According to Mendel (2004), FOI is most commonly understood primarily as a right to access information held by public bodies upon request. He notes further that a key element to the RTI is the obligation on public bodies to publish vital information, even in the absence of a request.

RTI guarantees the right of an unhindered access to public information held by all federal government branches and agencies, and often includes those of private institutions in which any federal, state or local government has controlling interest and those private institutions performing public functions. It means having access to government data, information, records, files, documents in any form (Omotayo, 2015). For instance, section 1(1) of the Nigerian Freedom of Information Act 2011 empowers all citizens to access or request both written 
and unwritten information in the custody or possession of any public official, agency or institution. The Act defines public institution as any legislative, executive, judicial, administrative or advisory body of the Government, including boards, bureau, committees or commissions of the State, and any subsidiary body of those bodies including but not limited to committees and sub-committees which are supported in whole or in part by public fund or which expends public fund and private bodies providing public services, performing public functions or utilizing public funds (s. 31). Information is defined as including "all records, documents and information stored in whatever form, including written, electronic, visual images, sound, audio recording, etc." The inference from these provisions is that it is virtually a no holds bar right of access to information. Omotayo (2015) observes that in some jurisdictions, it may mean not only allowing access to government documents in whatever form they happen to exist, but also opening up the meetings of governments, their advisory bodies and client groups to public scrutiny - the "open government" dimension (Transparency and Accountability Initiative, Opening Government (TAIOG), 2011; Soniyi, 2016). It may include access by individuals to files containing information about themselves and an assurance that the information is not being used for improper or unauthorised purposes.

Indeed, the right to information was as early as 1946 recognised as a fundamental right via Resolution 59(1) adopted during the first session of the United Nations General Assembly (Omotayo, 2015). It is considered as being an essential part of the right to freedom of expression by international human rights tribunals such as the Inter-American and European Courts of Human Rights; and, along with the United Nations, other foremost international authorities such as the Organisation of American States, Organisation for Security and Cooperation in Europe and the African Commission (TAIOG, 2011). For instance, Article 19 of the UDHR states that everyone has the right to freedom of opinion and expression. According to the United Nations, this right includes freedom to hold opinions without interference and to seek, receive and impart information and ideas through any media and regardless of frontiers (GAR 217A(III)). This position is reinforced by the proactive Supreme Court of India, which as far back as the early 70s held in Bennett Coleman \& Co $v$ The Union of India (1973) that the freedom of speech and expression is inclusive of the right of all citizens to read and be informed. This was later reaffirmed in Manubhai $v$ Life Insurance Corporation AIR (1981) when the court stated that "freedom of speech and expression is that all members should be able to form their beliefs and communicate them freely to others."

The utility of the RTI lies in the fact that, among others, it bridges the gap between the government and the people, making the former more responsive to the needs of the latter; and upholds the democratic ideology by promoting openness and transparency in administration, thus reducing corruption (Gopi, 2016). However, the realisation of this goal has a direct bearing on the impor- 
tance attached to the acquisition of information by both the government and the people. As James Madison aptly observes, "A popular government without popular information, or the means of acquiring it, is but a prologue to a farce or a tragedy or perhaps both. Knowledge will forever govern ignorance, and a people who mean to be their own governors, must arm themselves with the power knowledge gives." (Hunt, 2008)

\section{Institutional Obligations}

The FOIA creates for any person a right of access to information, whether or not contained in any written form, which is in the custody or possession of any public official, agency or institution. An applicant need not have any specific interest in the information sought and can apply to court to compel its release (ss.1 \& 2(6)) This forestalls the problem of locus standi, which has often hindered the pursuit of certain rights and underscores the fact that the interest or lack of interest of the applicant does not detract from the merit of the request. This is an important principle underlying the FOIA as reiterated by the United States Supreme Court in NARA v Favish (2004)

FOIA is often explained as a means for citizens to know "what the Government is up to." This phrase should not be dismissed as a convenient formalism. It defines a structural necessity in a real democracy. The statement confirms that, as a general rule, when documents are within FOIA's disclosure provisions, citizens should not be required to explain why they seek the information. A person requesting the information needs no preconceived idea of the uses the data might serve. The information belongs to citizens to do with as they choose.

It equally reinforces the fundamental nature of this right (Omotayo, 2015). An analogy could be drawn between it and the provision of the Fundamental Rights (Enforcement Procedure) Rules, 2009 on locus standi that the Court shall encourage and welcome public interest litigation in the human rights field and no human rights case may be dismissed or struck out for want of locus standi. The Rules noted, in particular, that human rights activists, advocates, or groups as well as any nongovernmental organisations, may institute human rights application on behalf of any potential applicant (Para 3(e), Preamble). The Court upheld this principle in Shobayo v C.O.P. [2009-2010]). It is equally exemplified in Alo v Speaker, Ondo State House of Assembly Anor (2018) where the Court of Appeal observed

For the sake of emphasis, possession of locus standi has been the bane of the citizens' advocates, in the public interest litigation, to query transparency and accountability in Nigeria. In a democratic dispensation, such as Nigeria's, the citizens have been proclaimed the owners of sovereignty and mandates that place leaders in the saddle. The requirement is a serious fracture of the citizens inalienable right to ventilate their grievances against poor governance vis a vis expenditure of public funds generated from their taxes. The sacrosanct provisions of section 1(2) of the Freedom of Information Act, 2011, which has ostra- 
cised this disturbing requirement, has, admirably, remedied the harmful mischief appurtenant to it.

The right of access to information clearly imposes corresponding obligations on public institutions. These obligations include not only the release of record or information in its custody, on request by any person, but also other obligations that are not contingent on request for information such as ensuring that its records are properly organised and maintained, and proactive publication of relevant information (Federal Ministry of Justice, 2013). This segment discusses the requirements of the Act in relation to the obligations of institutions and the challenges associated with these obligations.

\subsection{Obligations of Institutions}

\subsubsection{Obligation to Keep, Organise and Maintain Record}

Under section 2(1) and (2) of the Act, a public institution is obliged to ensure that it records and keeps information about all its activities, operations and businesses; and that it properly organises and maintains all information in its custody in a manner that facilitates public access to such information (s. 9(1) \& (2)). Additionally, section 2(5) mandates a public institution to update and review information required to be published under this section periodically, and immediately whenever changes occur. The essence of this is to ensure that relevant pieces of and changes in information are duly brought to the public domain without a prior request for disclosure. The problem, though, is that this provision is awkward and confusing. Are update and review to be done both periodically and immediately whenever changes occur? Or are they both to be done either periodically or immediately whenever changes occur? Or is one to be done periodically and the other immediately whenever changes occur? A review is something that can be done periodically and does not necessarily depend on the occurrence of a change in the system or nature of information whereas an update depends on the occurrence of a change. Surely there is an ambiguity that needs to be resolved here. The provision could be amended either to make both update and review to be undertaken periodically or make update subject to changes while review is undertaken periodically. Also the inclusion of "whenever" after "immediately" is a surplusage that should be dispensed with.

Depending on the intention of the legislature, suggested redrafts could read:

2(5) A public institution shall periodically update and review information required to be published under this section.

Or

2(5) For information required to be published under this section, a public institution shall

(a) update the information immediately changes occur; and

(b) review the information periodically.

Or

2(5) For information required to be published under this section, a public institution shall- 
(a) update the information immediately changes occur; or

(b) review the information periodically.

Section 10 criminalises the willful destruction of documents; or doctoring of documents by a public officer in custody of such documents before release to any person, entity or community applying for it. It imposes a minimum punishment of one year imprisonment on conviction by the court for the offence without an option of fine. By virtue of these provisions, public institutions must ensure that adequate measures are put in place to safeguard against records in their possession being tampered with and that such measures are strictly observed (Federal Ministry of Justice, 2013). This is a salient provision, but there could be a problem with its realisation as its practicality is questionable due to the requirement for proof beyond reasonable doubt for criminal offences. Without a further provision for verification of information and the power to inspect the information received, mere suspicion by an applicant requesting information that such information has been altered, will be insufficient to ground a conviction of the suspected public officer or head of an institution for such offence (Ogbuitepu, 2011). The provision of Schedule 23 of the United Kingdom Freedom of Information Act, 2000, allowing a judge to issue a warrant to the Commissioner to enter and inspect any office of a public authority, which refuses to release the information requested by an applicant, provides a better option.

The downside of prescribing a minimum sentence for offences must equally be noted. As much as the intention of the law to ensure adequate punishment for such serious offence is commendable, it is observed that such prescription may end up being counterproductive. A judge, who is sympathetic to an accused and feels that such minimum sentence is too onerous in any given circumstances, may rather discharge and acquit the accused on any justifiable ground, than convict and impose such prescribed minimum penalty. Invariably, it might be more result oriented to put a maximum ceiling on punishment and allow the judge the discretion to determine what measure to impose in the light of evidence before him or her.

\subsubsection{Disclosure of Information by Public Institutions}

Apart from the duty of a public institution to make information available on request by any person, it also has the obligation to publish certain specified information on a regular basis. This information is contained in section 2(3) of the Act as follows

A public institution shall cause to be published in accordance with subsection (4) of this section, the following information-

(a) a description of the organization and responsibilities of the institution including details of the programmes and functions of each division, branch and department of the institution;

(b) a list of all

(i) classes of records under the control of the institution in sufficient detail to facilitate the exercise of the right to information under this Act, and 
(ii) manuals used by employees of the institution in administering or carrying out any of the programmes or activities of the institution;

(c) a description of documents containing final opinions including concurring and dissenting opinions as well as orders made in the adjudication of cases;

(d) documents containing

(i) substantive rules of the institution,

(ii) statements and interpretations of policy which have been adopted by the institution,

(iii) final planning policies, recommendations, and decisions;

(iv) factual reports, inspection reports, and studies whether prepared by or for the institution;

(v) information relating to the receipt or expenditure of public or other funds of the institution;

(vi) the names, salaries, titles, and dates of employment of all employees and officers of the institution;

(vii) the rights of the state, public institutions, or of any private person(s);

(viii) the name of every official and the final records of voting in all proceedings of the institution;

(e) a list of-

(i) files containing applications for any contract, permit, grants, licenses or agreements,

(ii) reports, documents, studies, or publications prepared by independent contractors for the institution, and

(iii) materials containing information relating to any grant or contract made by or between the institution and another public institution or private organization;

(f) the title and address of the appropriate officer of the institution to whom an application for information under this Act shall be sent, provided that the failure of any public institution to publish any information under this subsection shall not prejudicially affect the public's right of access to information in the custody of such public institution.

As can be seen, this is quite an elaborate specification of classes of information or record, which every public institution must make available, except where the institution does not have the information or it falls under one of the exemptions provided by the Act (exemption of international affairs and defence, s. 11; exemption of law enforcement and investigation, s. 12; exemption of personal information, s. 14; exemption of third party information s. 15; exemption of professional or other privileges conferred by law s. 16; exemption of course or research material, s. 17; and denial by a public institution to disclose record pertaining to test questions, architects' and engineers' plan for building not constructed in whole or in part, s. 19 etc.). These provisions fall into three broad categories:

a. Descriptive information as contained in paragraphs (a) and (c);

b. List or enumeration of records as contained in paragraphs (b) and (e); and 
c. Actual records/data, the details of which are meant to be proactively disclosed by the institution as well as the appropriate officer to whom application for information is to be directed by the public, as contained in paragraphs (d) and (f) (Federal Ministry of Justice, 2013)

Proactive disclosure is useful because it reduces the volume of requests by citizens and, consequently, the workload of the desk officers. It equally promotes citizens' participation in decision making in governance by readily availing them of relevant information to address their concerns and make meaningful contribution. This enhances transparency and accountability in governance. Transparency and accountability, along with the rule of law are the pillars of good governance. Transparency and the rule of law are the basic tools for the enforcement of accountability (Johnston, 1993; Omotayo, 2015). Thus, transparency, accountability and good governance have been said to be inseparable (Owasanoye, 2000). This is anchored on the view that transparency as a concept in public office may be described as a commitment by all public and government institutions to be open and transparent in their policies and actions while accountability may be described as the responsibility of the same public officers and institutions to the people they purport to serve, including a willingness to submit to appropriate scrutiny for the office. As such, public officers should particularly be ready to give reasons for their actions, except where public interest consideration demands otherwise (Owasanoye, 2000). Indeed, the legitimacy of governments have been tied concepts such as accountability, transparency, responsiveness and meaningful participation; all of which are intimately intertwined and work together for the realisation of good governance (Obaidullah, 2001).

It is observed with respect to this obligation, though, that there are no sanctions against public institutions that fail to comply with some critical provisions of the Act. For instance, subsection (3)(f) requires the publication of the title and address of the appropriate officer of the institution to whom an application for information under this Act shall be sent, provided that the failure of any public institution to publish any information under this subsection shall not prejudicially affect the public's right of access to information in the custody of such public institution. Apart from paragraph (f) above, there are several relevant items of information a public institution is required to publish under this subsection. The use of "shall" in subsection 3 implies that this requirement is mandatory and not discretionary. Yet, the drafters of the Act did not see any need for sanction for failure to comply with this mandate other than that such failure "shall not prejudicially affect the public's right of access to information in the custody of such public institution." How possible is it for such failure not to prejudicially affect the public's right of access to such information? Indeed, such failure constitutes a stumbling block in the way of information seekers who have to spend extra time, energy and resources to get the details of relevant officers before they can apply for needed information. Indeed, it amounts to visiting the 
default of such public institutions on information seekers as exemplified in Unity Bank v Sokoto Rima and Rural Development Authority \& Anor (2015) where the Court held that where the law specifies a manner of performing a stated function, the party must comply and if it fails to do so, cannot visit this default on another party.

Without the force of sanction against noncompliance, law loses its efficacy, especially in a country like Nigeria where compliance with legal requirements is generally held in contempt. Indeed, it has been observed that noncompliance with these provisions by public institutions remains the greatest hindrance to the successful enforcement of the Act (Dunu \& Ugbo, 2014). Evidence shows too that in 2012, only 28 Ministries, Departments, and Agencies (MDAs) out of over 800 submitted the required report to the Attorney-General of the Federation (Enwerem, 2014). In 2016, the figure went up to 44, which is still just a fraction of 800 such institutions (Daily Trust Editorial, 2016). This shows the level of indifference of these MDAs and other public institutions to the success of the Act. Even the Attorney-General of the Federation, the chief implementing Officer of the Act is not free of blame in this regard as up till the end of 2014, the 2013 report was yet to be released to the public (Enwerem, 2014). The situation was, however, better in 2016 as the 2015 Annual Report was submitted to the National Assembly on 30 March 2016, which complied with the stipulated time frame of "on or before April 1 each year." (s. 29(7)). Worst of all, the National Assembly, the maker of the Act, up till 2016, had never submitted an annual report to the Attorney-General of the Federation since the inception of the Act (Daily Trust Editorial, 2016).

Additionally, subsection (4) mandates a public institution to ensure that information referred to in this section is widely disseminated and made readily available to members of the public through various means, including print, electronic and online sources (the differentiation between electronic and online sources is unnecessary as online sources are equally electronic), and at the offices of such public institutions. Revised copies of this information are to be made available to the public as well through the specified channels (s. 2(5)). Sadly, according to Ene Nwankpa, the National Coordinator of the Right to Know (R2K), a report conducted by the Organisation shows that of the earlier mentioned 44 institutions that submitted their reports in 2016, only the Bureau of Public Service Reforms (BPSR) has a dedicated FOI portal for receiving and responding to electronic requests and publishing information (Daily Trust Editorial, 2016).

\subsubsection{Obligation as to Time for Granting or Refusing Application}

Where a public institution receives an application requesting the disclosure of information, it is generally obliged to grant or refuse the request within seven (7) days of the receipt of the application. According to section 15 of the Interpretation Act, Cap I23 LFN 2004, the 7 days timeline is deemed to commence on the day after the FOI application is received by the public institution. This excludes holidays i.e. Sundays or public holidays. Where the application is denied, the in- 
stitution must give a written notice (Refusal Notice) to the applicant conveying the denial, the reason(s) for the denial and the section of the Act on which the denial is based (ss. 4 and 7(1)). Such refusal may be founded on the specified exemptions in ss 11,12, 14, 15, 16, 17 or 19 of the Act. The 2013 Guidelines on the FOI Act provides the full details of the content of the Notice, which must equally state the names, designation and signature of each person responsible for the denial of the application (s. 7(2)) The time limit for granting an application may, however, be extended for another seven (7) days where

a. The request is for a large number of records the provision of which will, within the original time limit, unreasonably interfere with the operations of the public institution; or

b. The provision of the information will necessitate consultation, which cannot be completed within the original time limit. In this case, the public institution must give a notice of the extension to the applicant. The notice must also indicate the applicant's right to have the decision to extend reviewed by the court (s.6).

Note that where a public institution fails to provide the requested information within the specified time limit, it shall be deemed to have refused access to the information (s.7(4)) The applicant can thus apply for a judicial review in line with section 20 of the Act as decided in Public \& Private Development Centre Ltd/GTE v Federal Ministry of Finance \& Anor (2014). Where a case of wrongful denial of access is established, the offending officer or institution is liable to a fine of N500,000 (s.7(5)). The case of Public \& Private Development Centre Ltd/GT (PPDC) v Integrated Parking Services Ltd. illustrates this. The applicant requested for certain information relating to the activities of the respondent. The respondent failed to respond to the request. The applicant applied to the court for a declaration and an order to compel the respondent to furnish the requested information. The court noted that by virtue of sections 2(7) and 31, the respondent is legally obliged to disclose the information requested by the applicant. In issuing an order of mandamus against the respondent, the court declared that the failure of the respondent to furnish the requested information amounted to a wrongful denial of information and a violation of section 1 of the FOI Act 2011.

It has been argued that the time frame provided by the Act is not practicable under the present circumstances in the country and indeed, evidence shows that as at the $18^{\text {th }}$ month of the coming into effect of the Act, all the requests granted, including by the Office of the Attorney-General, were done out of the statutorily mandated time frame (r2knigeria, 2013). This raises the question as to the reasonableness of this time frame. While it may be argued, on the contrary, that if the political will is present, the time frame is sufficient, especially with the additional extension of seven days provided for in the Act (s.6) it may be helpful to look at the position of the courts on reasonable time. In Nnajiofor \& Ors $V$ Ukonu \& Ors (1985) the Supreme Court held that whether the time for the hearing and determination of a case by a court or tribunal is reasonable is a question of fact to be decided according to the circumstances of each case. There 
is no hard and fast rule but all the circumstances ought to be taken into account in deciding what "a reasonable time" is. However, one may safely say that a period of time which causes the trial Judge to dim and lose his impression of witnesses cannot be reasonable.

Also in Soetan \& Ors V Steliz Ltd. \& Anor (2010) the Court of Appeal held that a reasonable time is also a moderately and practical possible time within which a court or tribunal could complete a trial and pronounce a decision. Again, in Effiom $v$ State (1995) it was held that reasonable time means the time which, in the search for justice, does not wear out the parties and their witnesses and which is required to ensure that justice is not only done, but appears to a reasonable person to be done. Note, however, that the phrase "does not wear out the parties and their witnesses" is subjective as it would then depend on the resilience limit of each party and the witnesses. Applying the court's view on reasonable time to the stipulated time limit for granting FoI requests, it can be implied that the sufficiency or otherwise of the time limit should be dependent on the facts and circumstances of each case. It must, nevertheless, not be such as to defeat the purpose of the request and must be such that it appears to a reasonable person that justice has been done. In Oilserve Ltd. $v$ L A Ibeanu \& Company Nigeria Ltd \& Anor (2007) the Court of Appeal defined a reasonable man as "a fair-minded man, rational in thought and orientation. $\mathrm{He}$ is a man endowed with reason. It includes the ordinary person seen on our streets, whose means of transport is the popular Okada or mammy wagon. It also includes the highly affluent, literate or otherwise." (see UBN Ltd. v Oredein (1992)).

To assist public institutions in properly and effectively complying with their responsibility under this segment of the Act, the Guidelines on the Implementation of the FOI Act, 2013 has provided a 10 stages response process, tagged the 10 "R"s under which a public institution is to act. These are: Register (register and record the application to note the date of receipt), Read (read the correspondence and decide whether it constitutes a request or not and if the institution actually holds the information requested), Record (maintain a formal system of making note of all applications and keeping record of all key actions taken in dealing with the application), Responsibility (as quickly as possible bring any received application to the notice of the appropriate department within the institution to ensure compliance with stated time limits), Retrieve (retrieve and consider all the relevant information subject to the application), Refer to others (where necessary consult with other relevant officials within and outside the institution), Redact and separate (extract the disclosable information by redaction), Review (response to a request should be reviewed by the person with the necessary authority to release or refuse the information), Reply (send a reply to the applicant in writing via the specified template), and Release to publication scheme under section $\mathbf{2}$ (where the information is likely to be of general public interest it should be included in the institution's publication scheme as part of materials to be proactively disclosed. 


\subsubsection{Institutional Framework and Training Obligation}

To facilitate the capacity of public institutions to proactively disclose information and ensure a smooth operation of the Act, the combined implication of sections 2(3)(f), 3(4), 13 and 29(1)(h) of the Act is that such institutions should designate appropriate staff with the responsibility to fulfill this mandate, in addition to managing the entire range of the FoI process. To this end, the Act provides that every government or public institution must ensure the provision of appropriate training for such officials on the public's right to access to information or records held by it (s.13). This is reinforced by the Guidelines on the Implementation of the Act (2013) indicating that the effective implementation of the Act requires each public institution to designate a senior official, who should be of at least Assistant Director Level or its equivalent as the head of a FOI Act Unit. The Unit is to have a direct responsibility for determining and generally ensuring compliance through the adoption of institutional best practices in the following areas

a. dedicated help/service lines or online assistance,

b. undertaking periodic review of record keeping and maintenance procedures,

c. reporting and liaising with the Office of the Attorney-General of the Federation,

d. preparation of a record map/chart,

e. compliance with the institution's proactive disclosure obligations,

f. regular training and retraining of the staff of the institution on their FOI related obligations.

Sadly, despite the salient provisions of the Act and Guidelines, there is an apparent lack of awareness of their content among MDAs. Public servants generally view persons seeking access to information on their records as adversaries who are out to witch hunt their institutions and, so, are usually unwilling to provide the needed information. Even designated officers in some MDAs are not adequately trained as interactions with them reveal a significant measure of lack of knowledge of the Guidelines and their responsibilities under it (Enwerem, 2014; Omonowa, 2012). Worse still, no designated officer that has failed to comply with the provisions of the Act has been sanctioned as provided in section 7(5) of the Act. For an effective fulfillment of their role, it is important that, in addition to providing appropriate training for these staff, institutions should go a step further in providing adequate protection for them beyond the protection from civil and criminal prosecution afforded them by section 27(1) and (2) of the Act. This is necessary because, being full time employees of their institutions, the critical nature of their responsibilities and their obligation to disclose required information may bring them in conflict with their superiors against whose interest disclosed information may work. This may lead to stigmatisation and victimisation and ultimately to the loss of job by such staff. The downside of this is that they may deliberately refuse to effectively perform their duties so as to avoid such conflict in order to secure their jobs (Ajanwachukwu, 2012). 


\subsection{Challenges Associated with Institutional Obligations}

One of the challenges associated with the obligations of institutions is the high rate of conservative system of storing public records by institutions, where such records exist at all. Most records are stored only in hard copies, often in rolled bundles or files, some of which sometimes either get torn or eaten up by rodents or insects. This slows down or affects the rate of compliance with the Act's provision in section 2(4) that information should be given in different forms, including electronically (Omonowa, 2012). Consequently, there is an urgent need for the computerisation of hard copy documents in custody of public institutions as record keeping is at the heart of the FOIA; it is the basis for the provision of requested information and proactive publication of information as demanded by the Act (r2knigeria, 2013). As noted by Sebina (2005) "legal provisions for access to information would be fruitless where good quality records are not created, where access to them is difficult, and where procedures are lacking on records disposal."

Another challenge is that the only provision made for the enforcement of the Act is recourse to the court both in situations where a public institution fails to keep a record of specified information and where it fails to disclose requested information (ss. 1(3), 2(6), 7, $20 \& 32$ ). The problems with these provisions are

a. Public institutions in Nigeria do not have a culture of record keeping even when the law mandates them to do so. In fact, there is a deliberate refusal to keep records either due to lack of proper appreciation of the importance of record keeping or as an attempt to cover up shady activities, which only preserved records would concretely disclose. To heighten the problem, little effort is usually made to enforce the law(s) requiring record-keeping. The extent of the problem is documented in the Report of the 2012 fuel subsidy investigation panel where the panel lamented that contrary to statutory requirements and other guidelines under the Petroleum Support Fund (PSF) Scheme mandating agencies in the industry to keep reliable information data base, there seemed to be a deliberate understanding among the agencies not to do so. This lack of record keeping contributed in no small measure to the decadence and rots the Committee found in the administration of the PSF. This is evident also in the budget preparatory process by MDAs where adequate data is not made available to the National Assembly. The Committee had to resort to forensic analysis and examination of varied and external sources (including the Lloyds List Intelligence) to verify simple transactions (Resolution No. (HR.1/2012).

More recently too at the 2016 National Youth Service Corps Freedom of Information Act Desk Officers Training Workshop in Abuja, this culture of poor record keeping was identified as one of the major challenges to the disclosure of information by public institutions. As noted by Mr. Edwin Megwa, the Head of NYSC FOIA Desk, the MDAs faced a challenge of record keeping, without which it was difficult to release information to the public (Vanguard, 2016). 
How then does the Act expect information seeking individuals to be the ones to compel public institutions to keep appropriate records through recourse to the court? This brings us to the second point.

b. Majority of Nigerians are litigation-averse; they would rather suffer in silence or seek extra-legal means to solve their problem than use the courts. Several reasons account for this, including lack of confidence in the judicial system or the high cost of legal proceedings. The snail pace of court proceedings coupled with the level of poverty in the country clearly does not encourage recourse to the court. It can, as such, be expected that even when relevant information is not published or people are denied access to requested information, they may not avail themselves the opportunity of recourse to the court. Indeed, the slow pace of court proceedings even in relation to actions taken under the FOIA, which the Act provides should be "heard and determined summarily" meaning it should be dealt with "without ceremony or delay, short or concise" (Garner, 1990) has been acknowledged. According to $\mathrm{Mu}$ muni, the Executive Director of the Socio-economic Rights Action Project (SERAP), their organisation, SERAP, had filed eight cases relating to request for Information which were denied by various public institutions and officials. One year after, these cases were still pending before the Court ... The Judges and the Lawyers (especially the Defence Counsel) in Freedom of Information application matters are yet to appreciate the intention and spirit behind Section 21 of the Act which envisages that proceedings in FOI Act must be conducted with dispatch (Mumuni, 2014).

This problem is not peculiar to Nigeria. With respect to South Africa and sections 1 and 78 of the Promotion of Access to Information Act 2 of 2000 (PAIA), which provide for recourse to the High Court, Calland (2009) describes the court appeal system as using "a hammer to smash a corn". Substantiating this, he noted that Kadar Asmal, Chair of the South African Ad Hoc Parliamentary Committee appointed to consider the future of Chapter 9 constitutional protection bodies, confirms this fact when he observed that "The complex and potentially expensive appeals mechanism provided for in the legislation places further obstacles in the way of ordinary individuals wishing to access information ... it is significant that only a handful of cases reach the courts."

Neuman (2004 \& 2009) in her extensive study of access to information law in different jurisdictions, reinforces the existence of this problem. She highlights its deeper implication in the observation that the cost, the delay, and the difficulty for citizens in accessing the courts have a chilling effect on the utilisation of this enforcement mechanism, and that with all these obstacles, the deterrent effect that courts often play is minimised and may actually encourage a perverse incentive among some civil servants to ignore the law or arbitrarily deny requests, as they recognise that most persons will not be able to effectively question their decisions. Reinforcing this, Omotayo (2016) further notes that the cumbersome and time consuming process of dragging requests for information through the 
Courts has a potentially negative effect on the utility of the information requested because of the time value of information.

Seeing that the requirement for recourse to the court could be counterproductive for most citizens, the question then, especially with regard to record keeping, is, is recourse to the court the most effective way to achieve the goal of the Act? The foregoing evidence shows that it certainly has not been. Again, assuming it is, why should it be the duty of concerned individual citizens alone to enforce it? Admittedly, the aim of the law cannot be to simply impose a burden on citizens, but it can make the realisation of the right the Act confers easier by reducing the challenges associated with it. Would it not help if the Act empowered the Attorney-General of the Federation and Minister of Justice, as a specifically mandated partial implementing officer of the Act (s.29) for instance, to set up a monitoring team to ensure compliance with the provisions of section 2 and any other relevant section(s) of the Act? Additionally, the Attorney-General could seek for means of providing appropriate administrative sanctions against noncompliance, which, no doubt, will make a positive impact in the general implementation of the Act.

Law enforcement is majorly the responsibility of the State rather than the citizens. Legitimate means of enforcement includes not only administrative and civil but also credible threat of coercive action to ensure compliance (Odinkalu, 2010). The relevance of law enforcement as identified by Odinkalu is apparent in the following reasons

a. It is inherent in separation of powers and in role allocation between the legislature, executive and judiciary.

b. It discharges responsibility of State to guarantee safety and security.

c. The ultimate responsibility of the State is enforcement of its will/laws.

d. Law enforcement is demonstration of State capability.

e. It is an assertion of State's monopoly of both legitimate use of coercion and adjudication.

The implication of this is that the means of enforcement provided by the Act is clearly not effective in the realisation of the goal of this Act. Without effective enforcement, a law is as good as dead. Sadly, available evidence shows that the Attorney-General of the Federation, the Government administering agent of the Act, has been largely inactive and ineffective in carrying out its responsibility of ensuring the full enforcement of the Act (Enwerem, 2014). Additionally, the manner in which public institutions handle the request for information contributes to the implementation challenges of the Act. Ogunleye (2015) chronicles the frustration information seekers have had to undergo in the hands of government agencies which refuse to disclose relevant information. Such refusal is usually based on the erroneous claim that the information requested constitutes an exemption on grounds of national security (s.11(1)) or that it is already in the public domain (s.27). This has prompted the remark that there is no longer an illusion that the FOI Act 2011 is a guarantee of unrestricted access to public infor- 
mation as provided in the law. "The atmosphere sustained by the Official Secret Act and many public servants who apparently belong to the 'old guard' are still so used to the practice of instinctively denying the people access to public information that it would take drastic action, mainly law suits, to force them to comply." (Ogunleye, 2015).

Also, it has been observed that while it is commendable that the judiciary consistently upholds the provisions of the FOI, it is regrettable that most public institutions are leaning in favour of the option of being dragged to court, where they proffer ridiculous defences that are invariably slammed by the court before they are ultimately compelled to disclose information which they have no legitimate reason to hide in the first place. Such an attitude is costly for citizens and costly for the public institutions themselves. It amounts to an unconscionable waste of public funds and ought to be checked. This reluctance to disclose persists notwithstanding the provision of section 28 of the Act that the fact that any information in the custody of a public institution is kept by that institution under security classification or is classified document within the meaning of the Official Secrets Act does not preclude it from being disclosed pursuant to an application for disclosure. This is in addition to section 27 which protects public officers from civil and criminal backlash for disclosure of information in good faith, irrespective of the provisions of the Criminal Code and the Official Secret Act.

It has been indicated that part of the challenges of implementation of the provisions of the Act in this regard is the failure of the Act to provide for Information Access Commissioner (IAC) who could serve as an ombudsman to ensure that individuals seeking access to information get adequate response to their complaints, including those relating to denials of information (Omotayo, 2015). This could indeed serve as a better alternative that could free information seekers from the challenges associated with personally seeking redress through court proceeding as earlier indicated. The utility of this alternative equally lies in the fact that being an independent entity, it will be easier for the IAC to investigate and, where relevant, institute court proceedings against defaulting institutions as against the Attorney-General, who as a stakeholder in the executive arm of government finds it difficult to institute such proceeding against another government institution for conviction and payment of penalties (Omonowa, 2012).

\section{Reporting Requirements}

The Act has elaborate provisions on reporting requirements both by public institutions and the Attorney-General of the Federation. In line with the mandate of the Act in section 29(5) that "the Attorney-General shall develop reporting and performance guidelines in connection with reports required by this section and may establish additional requirements for such reports as the Attorney-General determines may be useful", the former Honourable Attorney-General of the Federation, Adoke Bello, SAN, on 29 January 2012, published 
and circulated a Memorandum on the Reporting Requirements of the Act (HAGF/MDAS/FOIA/2012/1). Prior to this, the Federal Ministry of Justice had published Guidelines on the Implementation of the Freedom of Information Act 2011. In February 2013, a revised Edition of these Guidelines was also published. The Memorandum on the Reporting Requirements of the Act of January 2012 forms Chapter 13 of the Revised Guidelines. According to Adoke, open government requires agencies to work proactively and respond to requests promptly. The Guidelines are therefore intended to help public institutions understand their obligations under the Act and to promote good practice in the effective implementation of the FOI Act. This segment deals with the reporting obligation of public institutions and that of the Attorney-General and then addresses the challenges associated with the provisions.

\subsection{Public Institutions}

Section 29 (1) and (2) provides

(1) On or before February 1 of each year, each public institution shall submit to the Attorney-General of the Federation a report which shall cover the preceding fiscal year and which shall include-

(a) the number of determinations made by the public institution not to comply with applications for information made to such public institution and the reasons for such determinations;

(b) the number of appeals made by persons under this Act, and the reason for the action upon each appeal that results in a denial of information;

(c) a description of whether the Court has upheld the decision of the public institution to withhold information under such circumstances and a concise description of the scope of any information withheld;

(d) the number of applications for information pending before the public institution as of October 31 of the preceding year and the median number of days that such application had been pending before the public institution as of that date;

(e) the number of applications for information received by the public institution and the number of applications which the public institution processed;

(f) the median number of days taken by the public institution to process different types of application for information;

(g) the total amount of fees collected by the public institution to process such applications; and

(h) the number of full-time staff of the public institution devoted to processing applications for information, and the total amount expended by the public institution for processing such applications.

The essence of these reports, no doubt, is to give the Attorney-General an overall view of the public institutions appreciation of their reporting responsibilities and application of the provisions of the Act in this regard as well as a good grip on how the citizens are responding to the Law, i.e. whether or not they are 
taking advantage of the provisions of the Act. This should help the Attorney-General and, by extension, the National Assembly, to a reasonable extent, gauge the effectiveness of the Act and identify areas of further intervention, since, by virtue of section 29(7), the Attorney-General is statutorily required to make annual reports on these issues to the National Assembly. It seems odd, however, that the provision in section 29 requires public institutions to commence their report with applications on which they decided not to provide requested information way before proceeding to the ones on which they provided the requested information when the primary goal of the act is to provide access to information. Whether this was deliberate or not, it gives the impression that the primary expectation from public institutions is the refusal of information rather than its provision on request. If this is not the case, a proper rearrangement of this provision in the order of the primary goal of the Act will be apt.

(2) Each public institution shall make such report available to the public, among other means, by computer and telecommunications, or if computer and telecommunications means have not been established by the government or public institution, by other electronic means.

\subsection{Format of Report}

The Act does not specifically provide a format for the report to be provided by public institutions. The Guidelines on the implementation of the Act provided by the Attorney-General, however, specifies that a public institution must submit a report even if a nil entry is recorded under all or any of the subparagraphs provided for in section 29(1). It further indicates that all reports should be in Microsoft Excel format and must, in accordance with the Act, be submitted on or before February 1 of each year

(a) Electronically, via the following email address, fmoj.foi@justice.gov.ng OR foifmoj2011@gmail.com; and

(b) In hard copy, to Room 5E $07,5^{\text {th }}$ Floor, Federal Ministry of Justice Headquarters Building, Maitama, FCT, Abuja.

It is noteworthy that submission of report to the AGF by a public institution does not free it of its responsibility to proactively disclose to the public, in the prescribed manner, information and records pertaining to its administrative machinery and general operations as provided in section 2 of the Act.

\subsection{The Attorney-General}

Section 29 (3)-(8) provides the reporting responsibilities of the AGF. These are -

(3). Making each report submitted to him by public institutions available to the public in hard copies, online and at a single electronic access point.

(4). Notifying the chairpersons and ranking minority members of relevant committees of the National Assembly of the existence of the reports and making it available to them in electronic and hard copies not later than April of the year of the issue of the report. 
(5). Developing reporting and performance guidelines and establishing additional requirements for such reports as he deems useful. Consequent upon this, the AGF has, in order to ensure uniformity in the form and style for reports, designed and made available to public institutions relevant form for the purposes of submission of report to his Office.

(6). Exercising oversight responsibility towards ensuring compliance with the provisions of the Act by public institutions.

(7). Submitting to the National Assembly, not later than April 1 each year, an annual report for the previous calendar year indicating the number of cases arising from the Act, exemptions, disposals, costs, fees and penalties awarded.

(8). The report should equally include detailed description of the efforts made by the Ministry of Justice to encourage all government or public institutions to comply with the Act.

\subsection{Challenges Associated with Reporting Requirements}

The reporting requirements of the Act create some practicality problems. Among these are the provisions in sub-section (1) requiring each public institution to submit a report to the Attorney-General of the Federation (AGF) and sub-section (3) requiring the Attorney-General to "make each report, which has been submitted to him, available to the public in hard copies, online and also at a single electronic access point." The problem aspect of this provision is making each report available to the public in hard copies. Does it mean making a copy of each of these reports available to each member of the public? Or making it available at some location(s) where they can be accessed by the public? If the former is the intention, how practicable is it to make thousands of hard copies of such reports available to about 180 million Nigerians every year? What about the cost implication and other logistic problems, especially in the face of the gross underfunding problem of most public institutions? Clearly, this provision is ambiguous. It needs to be amended to clarify the situation and make it more practicable; probably by providing that hard copies should be made available on request by any member of the public. The United Kingdom's Freedom of Information Act, 2000 could serve as a reference here. Section 11(1) provides that an applicant can indicate his or her preference for the form in which requested information should be provided, which could be one or more of the following

a. the provision to the applicant of a copy of the information in permanent form or in another form acceptable to the applicant,

b. the provision to the applicant of a reasonable opportunity to inspect a record containing the information, and

c. the provision to the applicant of a digest or summary of the information in permanent form or in another form acceptable to the applicant.

The same practicality problem arises with respect to number 4 of subhead $B$ above requiring the AGF to notify the chairpersons and ranking minority members of relevant committees of the National Assembly of the existence of the re- 
ports and make it available to them in electronic and hard copies not later than April of the year of the issue of the report. How practicable is it for the AGF to make available to these chairpersons and ranking minority members a minimum of 800 hard copies of reports from all the public institutions in the country? The cost and storage implications, among others, of this yearly recurrent exercise can only be imagined.

So far, apart from the AGF's annual report to the National Assembly, which is sometimes not timely submitted, there's been no evidence of the AGF's compliance with this requirement. This may be due to the practicality challenge noted above. Credit must be given to the AGF for the timely development of the reporting and performance guidelines on the FOI Act, which has been quite helpful for public institutions that have been complying with the provisions of the Act. The same cannot, however, be said of the AGF in relation to his oversight responsibility to ensure that all institutions to which the Act applies comply with the provisions of the Act, as there has been evidence of gross noncompliance with the provisions of the Act, as shown in this paper, with no meaningful effort on the part of the AGF to checkmate this.

Sub-section (2) provides "Each public institution shall make such report available to the public, among other means, by computer and telecommunications, or if computer and telecommunications means have not been established by the government or public institution, by other electronic means." The question here is, beyond computer and telecommunications means, what other electronic means of transmission of such information/report exists?

Again, as under the institutional obligations, the Act does not provide any sanctions for failure to comply with the reporting requirements. It merely provides in section 29(6) that The Attorney-General shall in his oversight responsibility under this Act ensure that all institutions to which this Act applies comply with the provisions of the Act. This does not sufficiently address the problem of noncompliance with the provisions of the Act. The Guidelines provided by the Attorney-General to assist public institutions to efficiently discharge their reporting responsibilities have not yielded the desired result as many public institutions are in default. The Guidelines do not also contain any administrative sanctions. Obviously to meet the goal of the reporting requirements of the Act, the Act needs to provide penalty for noncompliance with these provisions.

\section{Recommendations and Conclusion}

\subsection{Recommendations}

a. The identified gaps in sections 2(5), 10 and 29(2) \& (3) of the Act should be filled.

b. Adequate sanctions should be provided for noncompliance with the provisions of the Act, especially with respect to section 2(3) and (4) on disclosure of information by public institutions. Additionally, the Attorney-General could seek for means of providing appropriate administrative sanctions 
against noncompliance, which, no doubt, will make a positive impact in the general implementation of the Act.

c. The provided sanctions in sections 7(5) and 10 should be diligently enforced.

d. The Act should empower the Attorney-General of the Federation and Minister of Justice, as a specifically mandated partial implementing officer of the Act, to set up a monitoring team to ensure compliance with the provisions of section 2 and any other relevant section(s) of the Act.

e. Adequate training should be regularly provided for FOIA desk officers.

f. To better preserve records and facilitate a timelier disclosure of information, public institutions should urgently computerise all the hard copy documents in their possession.

g. To resolve the practicality problem associated with the AGF making each report available to the public in hard copies, the Act should be amended to adopt the United Kingdom's provision allowing an applicant to indicate his or her preference for the form in which the requested information should be provided.

h. The Act should be amended to provide for Information Access Commissioner (IAC) who could serve as an ombudsman to ensure that individuals seeking access to information get adequate response to their complaints. It will be easier for an IAC to investigate and, where relevant, institute court proceedings against defaulting institutions as against the Attorney-General who by virtue of his position may find it difficult to sue another government institution.

\subsection{Conclusion}

Nigeria's Freedom of Information Act is a well thought out and deserved piece of legislation intended to assist the Country in the realisation of an effective and accountable government. Effectiveness, however, comprises not only the amplification of legal doctrine but also its implementation, impact and compliance. This paper has examined the institutional obligations and reporting requirements of Nigeria's FOIA 2011, which are aspects of the provisions aimed at making public records and information more freely available, providing for public access to public records and information as well as the established procedures for the achievement of the purposes set out in the Act.

As noted, these are salient provisions, compliance with which will largely achieve the goal of the Act. As shown in this work, however, there are substantive as well as syntactic gaps leading to ambiguity and practicality problem in the law, which constitute a challenge to the effective implementation of the Act. The law has a potential for success as evidenced in LEDAP $v$ the National Assembly, (2009) and a number of other cases cited in this paper indicate this. This success can only be more fully realised if the identified gaps are filled and the enforcement mechanism of the Act strengthened. It is, indeed, a common practice, in many jurisdictions for freedom of information laws to be periodically reviewed 
and amended to deal with unintended consequences and uncertainties touching on drafting or interpretation (Cabinet Office and Independent Commission on Freedom of Information Report, 2016). Very importantly, the will to ensure effective implementation of the Act must be garnered by the Chief Implementing Officer of these provisions, the Attorney-General of the Federation. As recommended, among others, the Act should be amended to provide sanctions for noncompliance with relevant provisions of the Act while already existing sanctions should be enforced against defaulting institutions and designated officers.

\section{Conflicts of Interest}

The author declares no conflicts of interest regarding the publication of this paper.

\section{References}

Ajanwachukwu, O. (2012). Strategies for the Enforcement of the Freedom of Information Act. In E. Azinge, \& F. Waziri (Eds.), Freedom of Information Law and Regulation in Nigeria (p. 236). Lagos: Nigerian Institute of Advanced Legal Studies.

Anukam, S. (2015). The Freedom of Information Act, 2011: Institutional and Reporting Requirements. Pressreader.

ARTICLE 19 (2007). Statement in Support of Freedom of Information in Nigeria.

Cabinet Office and Independent Commission on Freedom of Information Report. https://www.gov.uk/government/uploads/system/uploads/attachment_data/file/504139 /Independent_Freedom_of_Information_Commission_Report.pdf

Calland, R. (2009). Illuminating the Politics and the Practice of Access to Information in South Africa. http://foip.saha.org.za/uploads/images/PW_Chap1.pdf

Daily Trust Editorial (2016). Non-Compliance with FOI Act.

Dakas, D. C. J. (2009). Democratic Governance and the Rule of Law in Nigeria. In E. Azinge, \& B. Owasanoye (Eds.), Rule of Law and Good Governance (p. 278). Lagos: Nigerian Institute of Advanced Legal Studies.

Dunu, I., \& Ugbo, G. O. (2014). The Nigerian Journalists' Knowledge, Perception and Use of the Freedom of Information (FOI) Law in Journalism Practices. Journal of Media and Communication Studies, 1, 9.

Ekuno, M. (2001). Reasons for Non Implementation of Freedom of Information Bill. The Punch Newspapers 13th August 2010.

Enwerem, P. C. (2014) The Right to Know and the Implementation of Freedom of Information Legislation: Case Study of Nigeria and South Africa (p. 56). M.A. Thesis, Budapest: Central European University.

Federal Ministry of Justice, Abuja. (2013). Guidelines on the Implementation of the Freedom of Information Act 2011 (Revised ed., pp. 6, 10-11, 13-14, 38, 49).

Freedom of Information Coalition (2010).

Garner, B. A. (1990). Black's Law Dictionary, Centennial Edition (1891-1991). St. Paul: West Publication Co.

Gopi, M. (2016). Right to Information Act in India. Journal of Political Sciences \& Public Affairs, 4, 2. https://doi.org/10.4172/2332-0761.1000207

Hunt, G. (2008). The Writings of James Madison. Letter from James Madison to $W T$ 
Barry.

https://www.justice.gov/oip/blog/foia-post-2008-celebrating-james-madison-and-freed om-information-act

Inokoba, P. K. (2014). Freedom of Information Act and Democratic Consolidation in Nigeria: Prospects and Challenges. International Journal of Development and Sustainability, 3, 2259.

Johnston, M. (1993). Good Governance: Rule of Law, Transparency and Accountability.

Madubuike, N. J., \& Mbadugha, J. N. (2018). Obstacles to the Implementation of the Freedom of Information Act, 2011 in Nigeria. Nnamdi Azikiwe University Journal of International Law and Jurisprudence, 9, 105.

Mendel, T. (2003). Freedom of Information as an Internationally Protected Human Rights. Comparative Media Law Journal, 1, 1.

Mendel, T. (2004). Freedom of Information: A Comparative Legal Survey. http://unesdoc.unesco.org/images/0015/001584/158450e.pdf

Mumuni, A. (2014). Litigation Issues in Freedom of Information Act 2011. In 34th Advanced Course in Practice and Procedure, Module II (pp. 5-6). Lagos: The Nigerian Institute of Advanced Legal Studies.

Neuman, L. (2004). Access to Information Laws: Pieces of the Puzzle in the Promotion of Democracy through Access to Information, Bolivia. Atlanta, GA: Carter Center.

Neuman, L. (2009). Enforcement Models: Content and Context. Access to Information Working Paper Series.

http://siteresources.worldbank.org/EXTGOVACC/Resources/LNEumanATI.pdf

Obaidullah, A. T. M. (2001). Democracy and Good Governance: The Role of Ombudsman. Bangladesh: Institute of Parliamentary Studies. http://www.undp.org.bd/projects/prodocs/SPD/Obaidullah.pdf

Odinkalu, C. A. (2010). Human Rights and Law Enforcement (Agencies) (p. 4). International Human Rights Training Programme, Lagos: Nigerian Institute of Advanced Legal Studies.

Ogbuitepu, F. (2011). An Analysis on the Practicality of the Nigerian Freedom of Information Act 2011 (pp. 7-8).

Ogunleye, A. (2015). Govt Agencies Sabotage Freedom of Information Act. International Centre for Investigative Reporting.

https://www.icirnigeria.org/govt-agencies-sabotage-freedom-of-information-act

Omonowa, E. O. (2012). Some of the Challenges of the Implementation of the Current Guidelines on Freedom of Information Act 2011 (FOIA). Abuja: Federal Ministry of Justice and United Nations Development Programme's Consultative Forum on the Revised Guidelines on the Implementation of the Freedom of Information Act, Olusegun Obasanjo Auditorium, Federal Ministry of Justice, Complex.

Omotayo, F. O. (2015). The Nigerian Freedom of Information Law: Progress, Implementation, Challenges and Prospects. Library Philosophy and Practice (e-journal) 1219.

Owasanoye, B. (2000). Transparency, Accountability and Good Governance under the 1999 Constitution. In I. A. Ayua, D. A. Guobadia, \& A. O. Adekunle (Eds.), Nigeria: Issues in the 1999 Constitution (pp. 235-236). Lagos: Nigerian Institute of Advanced Legal Studies.

R2kNigeria (2013). Implementing Nigeria's Freedom of Information Act 2011: The Journey So Far, a Report on the Level of Awareness, Compliance and Implementation of the Freedom of Information Act, 2011, 18 Months after Its Enactment. http://www.r2knigeria.org/foi-assessment-reports 
Sebina, P. M. (2005). Access to Information: The Role of Freedom of Information Legislation and Constitutional Guarantees. ESARBICA Journal: Journal of Eastern and Southern African Regional Branch of the International Council on Archives, 24, 43. https://doi.org/10.4314/esarjo.v24i1.30994

Sendugwa, G. R. (2010). Legislating and Implementing Public Access to Information in Africa: What Are the Incentives for Government and Civil Society Actors? http://www.africafoicentre.org/index.php

Soniyi, T. (2016). Nigeria Becomes Member of Open Government Partnership. https://www.thisdaylive.com/index.php/2016/07/29/nigeria-becomes-member-of-open -government-partnership/

Torres, N. (2012). Access to Information in Columbia: 124 Years Later. http://www.freedominfo.org/2012/07/access-to-information-in-colombia-124-years-lat er

Transparency \& Accountability Initiative Opening Government TAIOG (2011). A Guide to Best Practice in Transparency, Accountability and Civic Engagement across the Public Sector.

http://freedominfo.org/documents/OGP2011pelimreportFinal\%20Document.pdf

Vanguard (2016). Why Implementation of Freedom of Information Act Has Been Stalled Stakeholders.

https://www.vanguardngr.com/2016/12/implementation-freedom-information-act-stall $\underline{\text { ed-stakeholders }}$ 


\section{Statutes}

Nigeria, (1999). Constitution of the Federal Republic of Nigeria.

Nigeria, (2011). Freedom of Information Act.

Nigeria, (2004). Interpretation Act, Laws of the Federation of Nigeria.

Nigeria (2004) Official Secrets Act Laws of the Federation of Nigeria.

United Kingdom, (2000). Freedom of Information Act.

\section{Cases}

Alo v Speaker, Ondo State House of Assembly Anor (2018) LPELR-45143 (CA). Bennett Coleman \& Co v The Union of India (1973) AIR 106, 1973 SCR (2) 757. Effiom v State (1995) 1NWLR (Pt 373) 505.

LEDAP v the National Assembly (2009) Suit No. FHC/ ID/155C/2009.

Manubhai v Life Insurance Corporation (1981) AIR Guj 15.

NARA v Favish (2004) 541 U.S. 157, 171-72.

Nnajiofor \& Ors v Ukonu \& Ors (1985) LPELR-2056 (SC).

Oilserve Ltd. v L. A. Ibeanu \& Company Nigeria Ltd \& Anor (2007) LPELR-5149 (CA).

Public \& Private Development Centre Ltd/GTE v Federal Ministry of Finance \& Anor (2014) Suit No. FHC/ABJ/CS/856/13.

Public \& Private Development Centre Ltd/GT (PPDC) v Integrated Parking Services Ltd., Motion No. M/3059/13.

Shobayo v C.O.P [2009-2010] CHR 209.

Soetan \& Ors v Steliz Ltd. \& Anor, (2010) LPELR-9051 (CA).

UBN Ltd. v Oredein (1992) 6 NWLR (Pt 247) 355.

Unity Bank v Sokoto Rima and Rural Development Authority \& Anor (2015) LPELR- 25946 (CA). 